\title{
A novel UGT1A1 gene mutation causing severe unconjugated hyperbilirubinemia: a case report
}

\author{
Xiaoxia Shi ${ }^{1^{*}} \mathbb{D}$, Sem Aronson ${ }^{1}$, Ahmed Sharif Khan ${ }^{2}$ and Piter J. Bosma ${ }^{1}$
}

\begin{abstract}
Background: Crigler-Najjar syndrome (CNs) presents as unconjugated hyperbilirubinemia, as a result of UGT1A1 deficiency, and can be categorized in a severe (type I) and mild (type II) phenotype. CNs type II patients usually benefit from phenobarbital treatment that induces residual UGT1A1 activity.

Case presentation: Here we present a CNs type II patient that is not responsive to phenobarbital treatment, which can be explained by two heterozygous mutations in the UGT1A1 gene. A 3 nucleotide insertion in the HNF-1a binding site in the proximal promoter previously reported in a Crigler-Najjar patient on one allele and a novel two nucleotide deletion in exon 1, resulting in a frameshift and a premature stop codon.

Conclusion: In newly diagnosed CNs patients with unconjugated bilirubin levels consistent with CNs type II but that are unresponsive to phenobarbital treatment, disruption of the HNF-1a binding site in the proximal promoter should be considered as a probable cause. Upon confirming a mutation in the HNF-1 a site, phenobarbital treatment should be stopped or at least be reconsidered because of its sedative effects and its teratogenic properties.
\end{abstract}

Keywords: Crigler-Najjar syndrome, UGT1A1, HNF-1a, Genetic analysis

\section{Background}

Crigler-Najjar syndrome (CNs) is a rare inherited liver disorder with a severely impaired metabolism of bilirubin, resulting in the accumulation of neurotoxic unconjugated bilirubin.

This deficiency of bilirubin glucuronidation is caused by mutations in the UGT1A1 gene encoding uridine diphosphate glucuronosyl transferase, resulting in impaired enzyme activity [1]. Clinically two types of CNs are recognized. In the most severe form, CNs type I, bilirubin glucuronidation is completely lacking, while in type II, some residual activity is present. The response to phenobarbital, that induces the expression of UGT1A1 by the mediating the binding of the constitutive androstane receptor (CAR; NR1|3) to the pBREM promoter region, is used in the clinic to distinguish both forms. In this report, we describe a second patient with a serum

\footnotetext{
* Correspondence: x.shi@amc.uva.nl

${ }^{1}$ Amsterdam UMC, University of Amsterdam, Tytgat Institute for Liver and Intestinal Research, Amsterdam Gastroenterology and Metabolism, Meibergdreef 69-71, 1105 BK, Amsterdam, The Netherlands

Full list of author information is available at the end of the article
}

bilirubin level normally seen in Type II that is unresponsive to phenobarbital.

\section{Case presentation}

A 14-year old female patient from Bangladesh presented with serum total bilirubin levels around $250 \mu \mathrm{mol} / \mathrm{L}$ and conjugated bilirubin (measured as direct bilirubin using the Diazo method) of around $10 \mu \mathrm{mol} / \mathrm{L}$, indicating a predominantly unconjugated hyperbilirubinemia. According to her parents' description, her weight at birth was around $2000 \mathrm{~g}$ and 4 days after birth, her skin turned yellow. Clinical assessment revealed an unconjugated hyperbilirubinemia of $220 \mu \mathrm{mol} / \mathrm{L}$ without signs of erythrocyte hemolysis (major cause: $\mathrm{ABO}$ or $\mathrm{Rh}$ incompatibility). After undergoing phototherapy for $4 \mathrm{~h}$ a day for 4 consecutive days the serum total bilirubin levels were reduced to $153 \mu \mathrm{mol} / \mathrm{L}$. The parents were advised to keep their daughter in the sunlight, but after a few months her serum total bilirubin increased again to over $300 \mu \mathrm{mol} / \mathrm{L}$. From this point onward, the patient did not receive treatment and no clinical data is available because the family lives in the country side and has limited access to medical care. Between the 
Table 1 Laboratory results between 2015 and 2018 show an unconjugated hyperbilirubinemia without signs of liver damage or hemolysis

\begin{tabular}{llll}
\hline Date & Test & Result & Unit \\
\hline 29/08/2018 & Total bilirubin & 241 & $\mu \mathrm{mol} / \mathrm{L}$ \\
& Albumin & 36 & $\mathrm{~g} / \mathrm{L}$ \\
15/10/2017 & Total bilirubin & 251.4 & $\mu \mathrm{mol} / \mathrm{L}$ \\
& Direct bilirubin & 10.2 & $\mu \mathrm{mol} / \mathrm{L}$ \\
20/12/2016 & Total bilirubin & 217.6 & $\mu \mathrm{mol} / \mathrm{L}$ \\
& Albumin & 46 & $\mathrm{~g} / \mathrm{L}$ \\
24/05/2016 & Total bilirubin & 255 & $\mu \mathrm{mol} / \mathrm{L}$ \\
23/03/2016 & Total bilirubin & 214.2 & $\mu \mathrm{mol} / \mathrm{L}$ \\
& Alanine aminotransferase (ALT) & 22 & $\mathrm{U} / \mathrm{L}$ \\
27/12/2015 & Total bilirubin & 210.7 & $\mu \mathrm{mol} / \mathrm{L}$ \\
& Direct bilirubin & 1.7 & $\mu \mathrm{mol} / \mathrm{L}$ \\
& Alkaline Phosphatase (ALP) & 87 & $\mathrm{U} / \mathrm{L}$ \\
& Gamma-GT ( $\boldsymbol{\gamma}$-GT) & 18 & $\mathrm{U} / \mathrm{L}$ \\
$21 / 12 / 2015$ & Hemoglobin & 12.20 & $\mathrm{~g} / \mathrm{dL}$ \\
& Reticulocyte & 0.86 & $\%$ \\
& Total bilirubin & 247 & $\mu \mathrm{mol} / \mathrm{L}$ \\
& ALT & 21 & $\mathrm{U} / \mathrm{L}$ \\
\hline
\end{tabular}

age of 14 and 17 years her serum total bilirubin levels have been monitored and where stable around $200-250 \mu \mathrm{mol} /$ L. Liver damage markers in serum were low (ALT) and a hemolytic cause of the hyperbilirubinemia was excluded with normal hemoglobin and reticulocyte levels (Table 1). These serum bilirubin levels without any treatment are in line with those seen in Crigler-Najjar syndrome $(\mathrm{CNs})$ type II, indicating a partial deficiency of UGT1A1. However, inducing the residual UGT1A1 activity by administrating phenobarbital $(30 \mathrm{mg} /$ day $)$ did not result in a significant change in total bilirubin (Table 1). The coding region and intron-exon boundaries of the UGT1A1 gene of the patient and parents was sequenced to determine what caused UGT1A1 deficiency and the absence of a response to phenobarbital.

\section{Sequencing of the UGT1A1 gene coding and promoter region}

Sanger sequencing was used to determine the nucleotide sequence of amplified fragments of UGT1A1 gene and promoter region as previously described $[2,3]$. The purified amplicons were sequenced using the internal primers listed in Additional file 1: Table S1.

\section{Genetic analysis of the UGT1A1 gene and promoter}

The patient was found to have two heterozygous mutations in the UGT1A1 gene (Fig. 1). The first is a 3 nucleotides insertion in the HNF- $1 \alpha$ binding site in the proximal promoter, which was also found in her mother. The second mutation is a two nucleotides deletion in exon 1 (266_267delGT), which was found in her father. This two nucleotide deletion has not been described in literature before and results in a frameshift with a predicted premature stop codon at position 279_281TAG in exon 1.

\section{Discussion and conclusion}

Here we present a patient with an unconjugated serum bilirubin level reported for patients with CNs type II [4], that does not respond to phenobarbital treatment. The patient appeared to be heterozygous for two different UGT1A1 mutations.

The mutation derived from her mother, a 3 nucleotide insertion in the HNF- $1 \alpha$ binding site in the proximal promoter, was identical to the mutation we found in a $\mathrm{CNs}$ patient with a similar phenotype that we reported recently,

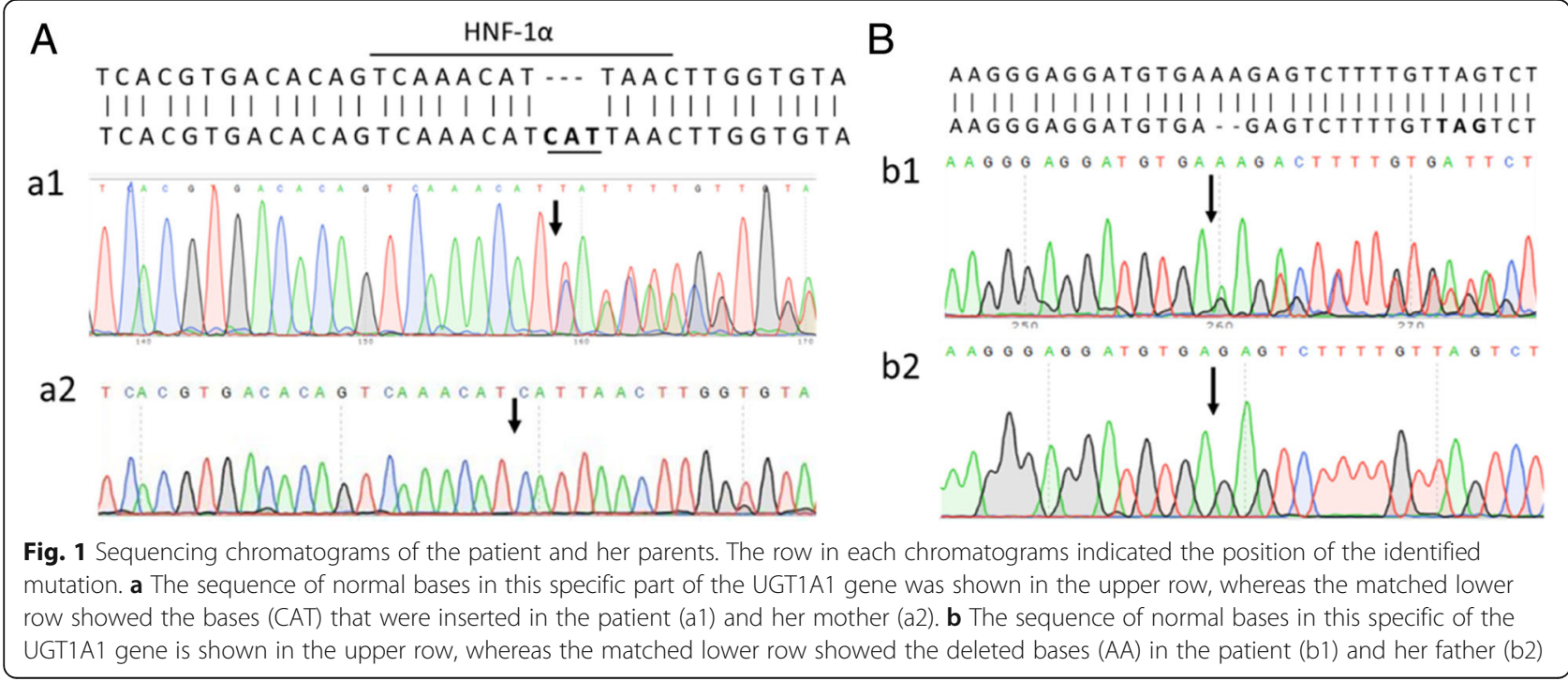


this 3 nucleotide insertion caused a strong reduction of basal promoter activity $(-95 \%)$ and made the promoter non-responsive to CAR activation and to a potential alternative treatment via PXR activation with rifampicin which were confirmed by the functional promoter studies in that report. Due to this mutation, a minute amount of mRNA will be transcribed from this allele, which encodes for a minimal amount of normally active protein, and renders this allele unresponsive to UGT1A1 inducing drugs, including phenobarbital treatment.

The two nucleotide deletion in exon 1 of the UGT1A1 gene, inherited from her father, is a novel mutation. This mutation has not been described before and is predicted to result in a premature stop codon by frameshift leading to the formation of a truncated and inactive enzyme that will most likely be degraded.

The combination of these two mutated alleles results in a severely impaired UGT1A1 function, which is in line with the high levels of unconjugated hyperbilirubin seen in this patient. Unconjugated bilirubin levels in serum of this patient were comparable to that seen in the previous patient with an identical HNF-1a mutation, indicating the phenotype results from this mutation only. Since, the HNF-1 $\alpha$ mutation renders the gene unresponsive to transcriptional activation of the UGT1A1 gene by phenobarbital, phototherapy and liver transplantation are currently the only therapeutic options.

We report a second patient with a CNs type II phenotype that is unresponsive to phenobarbital treatment due to a mutated HNF-1 $\alpha$ binding site, in combination with a novel nonsense mutation. In newly diagnosed $\mathrm{CNs}$ patients with a similar phenotype, looking for mutations in the HNF1a binding site seems a good strategy. Upon confirming presence of a mutated HNF-1a binding site the use of phenobarbital should be reconsidered in view of its sedative effect and specifically in women, because of its reported teratogenic properties [5].

\section{Additional file}

Additional file 1: Table S1. Primer used to amplify UGT1A1 gene. (DOCX $18 \mathrm{~kb}$ )

\section{Abbreviations}

ALT: Alanine transaminase; CNs: Crigler-Najjar syndrome; HNF-1a: Hepatocyte nuclear factor 1a; UGT1A1: UDP-glucuronosyltransferase $1 \mathrm{~A} 1$

\section{Acknowledgments}

We thank the family member who sent us samples and provided clinical information for our study. XS is recipient of a fellowship of the China Scholarship Council (CSC).

\section{Authors' contributions}

XS and PB have carried out the molecular genetic studies and the sequence alignment and drafted the manuscript. SA contributed to write the manuscript. ASK provided the clinical information and samples. All authors read and approved the final manuscript.
Funding

No applicable.

\section{Availability of data and materials}

All used data and materials are available upon request, please contact P.J. Bosma.

Ethics approval and consent to participate

Because only retrospective data was collected for this case report, the Medical Research Involving Human Subjects Act (WMO, local regulation) does not apply and official approval of this study by our local ethics committee is not required.

\section{Consent for publication}

Formal written consent for genetic analysis and publication was provided by the patient and her parents.

\section{Competing interests}

The authors who have taken part in this study declared that they do not have anything to disclose regarding funding or conflict of interest with respect to this manuscript.

\section{Author details}

${ }^{1}$ Amsterdam UMC, University of Amsterdam, Tytgat Institute for Liver and Intestinal Research, Amsterdam Gastroenterology and Metabolism, Meibergdreef 69-71, 1105 BK, Amsterdam, The Netherlands. 'Square Pharmaceuticals Ltd, BD, Dhaka Unit, Kaliakair, Gazipur, Bangladesh.

Received: 6 December 2018 Accepted: 22 May 2019

Published online: 29 May 2019

References

1. Bosma PJ. Inherited disorders of bilirubin metabolism. J Hepatol. 2003;38(1): 107-17.

2. van Dijk R, Mayayo-Peralta I, Aronson SJ, Kattentidt-Mouravieva AA, van der Mark VA, de Knegt R, Oruc N, Beuers U, Bosma PJ. Disruption of HNF1alpha binding site causes inherited severe unconjugated hyperbilirubinemia. J Hepatol. 2015:63(6):1525-9.

3. Bosma PJ, Chowdhury NR, Goldhoorn BG, Hofker MH, Oude Elferink RP, Jansen PL, Chowdhury JR. Sequence of exons and the flanking regions of human bilirubin-UDP-glucuronosyltransferase gene complex and identification of a genetic mutation in a patient with Crigler-Najjar syndrome, type I. Hepatology. 1992;15(5):941-7.

4. Arias IM, Gartner LM, Cohen M, Ezzer JB, Levi AJ. Chronic nonhemolytic unconjugated hyperbilirubinemia with glucuronyl transferase deficiency. Clinical, biochemical, pharmacologic and genetic evidence for heterogeneity. Am J Med. 1969:47(3):395-409.

5. Ashtarinezhad A, Panahyab A, Shaterzadeh-Oskouei S, Khoshniat H, Mohamadzadehasl B, Shirazi FH. Teratogenic study of phenobarbital and levamisole on mouse fetus liver tissue using biospectroscopy. J Pharm Biomed Anal. 2016:128:174-83.

\section{Publisher's Note}

Springer Nature remains neutral with regard to jurisdictional claims in published maps and institutional affiliations.
Ready to submit your research? Choose BMC and benefit from:
- fast, convenient online submission
- thorough peer review by experienced researchers in your field
- rapid publication on acceptance
- support for research data, including large and complex data types
- gold Open Access which fosters wider collaboration and increased citations
- maximum visibility for your research: over $100 \mathrm{M}$ website views per year
At $\mathrm{BMC}$, research is always in progress.
Learn more biomedcentral.com/submissions 